\title{
Policy instruments for renewable energy: an empirical evaluation of effectiveness
}

Article

Accepted Version

Azhgaliyeva, D., Belitski, M., Kalyuzhnova, Y. and Romanov, M. (2018) Policy instruments for renewable energy: an empirical evaluation of effectiveness. International Journal of Technology Intelligence and Planning, 12 (1). pp. 24-48. ISSN 1740-2840 doi: https://doi.org/10.1504/IJTIP.2018.094409 Available at https://centaur.reading.ac.uk/80485/

It is advisable to refer to the publisher's version if you intend to cite from the work. See Guidance on citing.

To link to this article DOI: http://dx.doi.org/10.1504/IJTIP.2018.094409

Publisher: Inderscience

All outputs in CentAUR are protected by Intellectual Property Rights law, including copyright law. Copyright and IPR is retained by the creators or other copyright holders. Terms and conditions for use of this material are defined in the End User Agreement.

\section{www.reading.ac.uk/centaur}

\section{CentAUR}

Central Archive at the University of Reading 
Reading's research outputs online 


\title{
Policy instruments for renewable energy: An empirical evaluation of effectiveness
}

\begin{abstract}
This paper evaluates the effectiveness of renewable energy policy instruments on wind energy production using annual data from 106 countries over the period 1997-2014. Eleven policy instruments are evaluated: direct investment, feed-in tariffs, grants and subsidies, loans, taxes, green certificates, information and education, strategic planning, codes and standards, research, development and deployment and voluntary approaches. The empirical evidence uncovers the impact of different policy instruments on wind energy production. The model tests which policy instruments are effective in promoting wind energy, and whether their effectiveness depends on their existence, experience, implementation or combination. The results of the Mean Group estimation show that two policy instruments have positive impact on wind energy production: tax incentives and the strategic planning. The impact of strategic planning increases with a number of policy changes.
\end{abstract}

Keywords: policy instruments; policy measures; wind energy; wind power; renewable energy production; renewable energy sources; energy policy. 


\section{Introduction}

Electricity can be generated from non-renewable energy sources such as fossil fuels or renewable energy, such as solar, wind and hydro. It is important to have a balance in using fuel sources and renewable energy sources in electricity generation process, to balance power systems. Moreover, such a balance would protect the governments from overreliance on one single type of power generation. Renewable technologies use natural energy, such as wind, wave, tidal, hydro, biomass, geothermal and solar, to produce electricity. Many countries are promoting a switch to renewable energy sources in order to achieve sustainable growth (Menanteau, et al., 2003; Carley, 2009; Sawin and Flavin, 2006).

World renewable energy production (excluding hydro) has grown fast over the last decade (Figure 1). The growth is explained by the production of wind and solar energy, possibly due to a sharp price reduction of solar modules and wind turbines. Since renewable energy sources, solar panels and wind turbines, are tradable, solar and wind energy generation should have been affected in all countries. Unfortunately, the growth of renewable energy production is driven by only several countries, such as Germany, People's Republic of China, United States of America, India, Spain, Japan, Italy and United Kingdom (Figure 2). This study investigates what are the drivers of renewable energy production and what is the role of renewable energy policy.

The need for government support of renewable energy is often justified by the existence of barriers (Beck and Martinot, 2004) and positive externalities from renewable energy (Menanteau, et al., 2003). Barriers to renewable electricity generation include subsidies to electricity generated from fossil fuels, high initial capital costs, lack of skills or information and uncertainties (Beck and Martinot, 2004). Policies targeting to promote renewable energy aim to reduce these barriers. Their effectiveness in promoting renewable energy production depends on how well such policy instruments are able to reduce/ease existing barriers. The need for government intervention to increase renewable energy production is explained by positive externalities of renewable energy. Positive externalities of renewable energy include reduction of pollution, greater energy access and energy sources diversification. The presence of positive externalities means that without government intervention, less renewable energy is provided in the market than the socially optimal quantity. The need to switch from nonrenewable electricity sources is justified by negative externalities of electricity generation using fossil fuels, which causes pollution (Menanteau, et al., 2003). Renewable energy policies are needed to help renewable energy producers to overcome market barriers and to increase renewable energy generation.

Policies targeting to promote renewable energy aim to increase energy generation from renewable energy sources, reducing carbon emissions and improving energy security (Carley, 2009; Sawin and Flavin, 2006). The existing literature investigates the effectiveness of policies targeting to increase generation of renewable energy, using different empirical methods and data samples. This study contributes to the debates related to the effectiveness of renewable energy policy instruments in electricity generation.

This study uses a large panel data set of 106 countries, which allows us to compare and contrast a wider range of policy instruments, as well as their combinations. The time period for empirical analysis of wind energy is limited. The earliest electricity generation using wind power started in 1978, by Denmark, which remained the only producer until 1982. In 1983 Sweden began to generate electricity using wind power. Only in 1996 did the number of countries producing electricity using wind power reach 30 (Figure 3 ). That is why most of the 
empirical literature uses annual data of renewable electricity generation starting from 1980s (Zhao, et al., 2013) or 1990s (Aguirre and Gbenga, 2014; Carley, 2009).

This paper addresses the following research question: what are the most effective renewable energy policy instruments, and what are the conditions for their effectiveness? To answer these research questions we investigate the drivers of renewable energy production, using the case of electricity generation by wind turbines, and paying particular attention to policy instruments. Eleven policy instruments are considered: direct investment, feed-in tariffs/premiums, grants and subsidies, loans, taxes, green certificates, information and education, strategic planning, codes and standards, research, development and deployment (RD\&D) and voluntary approaches.

Feed-in tariffs aim to attract investments in renewable energy by offering long-term guaranteed purchase agreements with a government on electricity generated from renewable energy sources. Premiums are also included in feed-in tariffs, as they allow an additional premium for sold electricity to be received on top of the market price. Premiums guarantee an additional payment for electricity sold to the grid on top of the market price, while feed-in tariffs guarantee a fixed price on electricity sold to the grid (Klein 2008; Mendonca et al. 2009). Green certificates, or renewable energy certificates, are tradable certificates, which allows the trade of renewable energy quota obligations. Obligations are set by the government, as a minimum share of energy generated or consumed. Green certificates are earned by producing/consuming renewable energy or purchased (Beck and Martinot, 2004). In the UK green certificates are known as Renewables Obligation Certificates. For a review of each policy instrument see Beck and Martinot (2004), Jacobsson et al. (2009), Haas et al. (2004), IRENA (2012), Menanteau et al. (2003), Sawin and Flavin (2006) and Winkler (2005).

This paper identifies not only which policy instruments are effective in promoting wind energy, but also whether their effectiveness depends on how long these policy instruments exist (experience), their changes, quality of implementation and combination with other renewable energy policy instruments.

The remaining sections of this paper are structured as follows. Section 2 reviews literature. Section 3 discusses methodology and data. Section 4 presents empirical results. Section 5 concludes.

\section{Literature review}

In the existing literature the policy instruments which are used to promote renewable energy are widely discussed (e.g. Del Río and Mir-Artigues, 2014; Karatayev, et al., 2016; Menanteau, 2003; Polzin et al., 2015). Theoretically, price-based and quantity-based approaches are seen as comparable methods for achieving targets in usage of renewable energy. However, it is not straightforward to take into account the reality of uncertainty and the relative efficiency of these instruments in sustainable technical change (Menanteau, 2003). It is important to stress that each country forms its own incentive policies to promote renewable energy development and that at the present there is no textbook prescription for a universal approach in this matter. All these policies are derived from different criteria (relevant to the country's targets, aspirations, etc.) when evaluation of such incentives is taking place. For example, promotion of wind and solar energy through a renewable energy certificate system in India had only limited success, while the UK experience with the tradable renewable energy certificate system was more profound. The UK green certificates 
scheme, Renewable Obligation Certificate, contributed effectively to widen the UK energy and climate change goals (Chatterjee, et al. 2013).

A variety of instruments exist to stimulate the growth of renewable power generation; however, the governments need to realise that although these are important instruments in stimulating the development of different technologies, they remain interim measures since they do not always lead to cost reduction (Ackermann et al., 2001). There are different market schemes such as a bidding process, which could assist in reducing costs, or fixed quotas, which could be used together with green certificate trading or a power exchange in combination with Green Pricing. At the present time there are only few cases where such instruments have been implemented (Byrnes et al., 1999), that is why they are excluded from this study.

In practice, for political and institutional reasons, the governments are faced with challenges when they attempt to implement renewable energy promotion instruments. A number of studies have highlighted that overall possible barriers that could delay the growth of renewable energy implementation are financial, technical, regulatory/institutional and information/educational barriers which should be addressed for feasible development in different countries according their level of development, financing, etc. (Del Río and MirArtigues, 2014; Kousksou, et al., 2015).

Application of renewable energy varies between countries and even within the same country across regions. Governments and regulatory authorities across the globe have adopted a variety of specific policy measures to encourage development of wind and other renewable energy sources. Former illustrates a significant disagreement in policy implementation within the US. Some states (e.g., California, Minnesota, and Oregon) have been aggressively promoting wind and other renewable energy sources for some time, while others (e.g., Alabama, Mississippi, and South Carolina) have taken little or no action in this regard.

As the type and set of policies toll box implemented by nations grows, so is the need to evaluate how effective and significant they are in promoting renewables increases. Some empirical literature investigates the impact of policy instruments on renewable energy using one country across regions/states, such as Carley (2009) and Menz and Vachon (2006), while others use cross-country analysis, such as Aguirre and Gbenga (2014), Baldwin et al. (2017), Carley et al. (2016), Johnstone et al. (2010), Marques et al. (2010), Romano et al. (2017); Zhao et al. (2013). However, major findings remain controversial, possibly due to different data samples, measures of variables and methods of estimation. Another explanation of controversial results in the prior literature is that the impact of renewable energy policy instruments varies across renewable energy sources (Sawin and Flavin, 2006; Zhao, et al., 2013). Table 1 provides a summary of empirical results of the impact of renewable energy policy instruments on renewable energy.

\section{Methodology}

\subsection{Data}

Data set consists of annual data across 106 counties over the 18 year-period (1997-2014). All variables vary across years and countries, except for coal price and wind turbine price. Coal price and wind turbine price vary by year, but not by countries. Our data is collected from five sources, International Energy Agency (IEA), 2017; Kaufmann, et al., 2010; British Petroleum (BP), 2017; International Renewable Energy Agency (IRENA), 2017; and IEA and IRENA, 2017. Our data sample includes countries which data is available across all five data sources (106 countries). 


\subsection{Dependent variable}

\section{Wind energy}

In order to identify the dependent variable, it is important to understand the objectives of renewable energy policies. Renewable energy policy objectives vary across countries, however the majority of policy objectives aim to increase renewable energy generation, reduce emissions and improve energy security (Carley, 2009 and Sawin and Flavin, 2006). In this study we measure the impact of policy instruments on wind energy production. However, other objectives of renewable energy policies, such as capacity and emissions, can be included in future studies.

Renewable energy used to generate electricity includes wind, wave, tidal, hydro, biomass, geothermal and solar. Policy instruments also vary by renewable energy sources due to differences in technology cost. Thus, it is important to study the impact of policy instruments separately by renewable energy source. Wind energy is the most attractive for empirical study, as production of wind energy started to increase sharply from 1978 and is the largest renewable energy after hydro energy (Figure 4). This is why this paper investigates the impact of policy instruments on wind energy, rather than on other types of renewable energy or on renewable energy as a whole. Nevertheless, this methodology can be applied to other renewables.

The dependent variable, wind energy, is electricity generated by wind turbines (both off-shore and on-shore), measured as a share of electricity generated from all sources, including nonrenewable, and multiplied by $100 \%$.

\subsection{Policy variables}

Energy policies can play a crucial role in promoting renewable energy production. Many countries set renewable energy policy targets as a share of renewable energy in primary/final energy or electricity generation, including/excluding hydro energy or as a renewable energy generation by energy sources by different target years (usually between 2020 and 2050). Renewable energy policy targets cannot help to meet objectives on their own. In order to affect economic behaviour, special instruments are needed which are capable of changing the behaviour of consumers or producers of renewable energy. Such instruments are called renewable energy policy instruments.

Countries use policy instruments, i.e. feed-in tariffs, green certificates, etc., to meet renewable energy policy targets. These policy instruments usually aim to affect producers or consumers of renewable energy. Feed-in-tariff is the most popular renewable energy policy instrument (Table 2 and Figure 5).

The policy instruments which are included in this study are identified based on the classification as in the Joint Policies and Measures database for Global Renewable Energy (IEA and IRENA, 2017), which is constructed by the IEA and the IRENA, as well as on the number of countries which set policy instruments in each category (Table 2). IEA and IRENA (2017) database includes information on renewable energy policy instruments from 117 countries from 1974. Not all policies aim to affect wind energy (Table 2), thus only 
policy changes which aim to affect electricity generation by wind turbines are included. Eleven policy instruments are included in this study: (1) direct investment, (2) feed-in tariffs/premiums, (3) grants and subsidies, (4) loans, (5) taxes, (6) green certificates, (7) information and education, (8) strategic planning, (9) codes and standards, (10) RD\&D and (11) voluntary approaches. This study employs five policy measures: (1) existence, (2) experience, (3) changes, (4) implementation and (5) combination.

\section{Policy existence}

Policy instruments can be measured as simple dummy variables, which are equal one after policy instruments are set and zero before, as in Aguirre and Gbenga (2014), Carley (1999), Johnstone et al. (2010) and Zhao et al. (2013).

\section{Policy experience}

The effectiveness of policy instruments might improve over time due to experience. Thus, policy instruments can be measured as a number of years of experience, which is calculated as the difference between the current year and the year when policy instruments were set. The number of years of existence of the policy measures the countries' experience with such policy instrument. This measure allows to identify whether the effectiveness of policy instruments depends on a country's experience.

\section{Policy changes}

Countries can learn from experience and improve policy through changes. Thus, policy instruments can be measured by a number of policy changes, which takes value zero before policy is set, one after the policy is set, two after the first policy change, three after the second policy change and so on. This measure allows to identify whether the effectiveness of policy instruments depends on the number of policy changes.

\section{Policy implementation}

The effectiveness of policy instruments might depend on the quality of their implementation. Thus, policy implementation is included to measure the quality of the implementation of policy instruments. Policy implementation is measured as an interaction term of policy dummy variable, policy existence, with government effectiveness index (World Bank, 2017). Government effectiveness index measures "perceptions of the quality of public services, the quality of the civil service and the degree of its independence from political pressures, the quality of policy formulation and implementation, and the credibility of the government's commitment to such policies" (Kaufmann, et al., 2010). It ranges from -2.5 (least effective) to 2.5 (most effective).

\section{Combination of policies}

The effectiveness of policy instruments depends on whether the right combination of policy instruments is adopted (Sawin and Flavin, 2006). The efficient combination of policy instruments depends on countries' needs, circumstances and available resources (Sawin and Flavin, 2006). The combination of economic and non-economic policy instruments (Table 2) are included to test whether the effectiveness of economic policy instruments (feed-in tariffs; taxes, direct investment; loans; green certificates; and grants and subsidies) is conditional on non-economic policies (voluntary approaches; information and education; strategic planning; codes and standards; and RD\&D). Interaction terms (i.e. product) of six economic policy instruments (feed-in tariffs; taxes, direct investment; loans; green certificates; and grants and subsidies) with other policy instruments (non-economic) are generated. Using six interaction terms we test whether the effectiveness of policy instruments depends on the combination of 
policies adopted (Sawin and Flavin, 2006). Policy interaction terms measure the impact of a specific policy conditional on the implementation of other policies.

\subsection{Control variables}

Control variables which are included are similar to the existing literature (Aguirre and Gbenga, 2014; Zhao, et al., 2013), GDP per capita, price of coal, CO2 emission as a share in GDP. Also the price of wind turbines is included.

\section{Coal price}

Price of coal measures the price of a substitute. The substitute to the wind energy is fuelbased electricity generation. Electricity price across all countries included in our sample is not freely available. Instead, price of major fuels, namely coal, natural gas and crude oil, can be used (Figure 6). However, their prices are correlated (Figure 7). Thus, we use coal price, which is the major fuel to produce electricity in the world (Figure 6).

\section{Wind turbine price}

Price of wind turbines captures not only the cost of wind turbines but also technological improvements, because the price of wind turbines is measured in US dollars per kW. Price of wind turbines is available from 1997, which explains the sample period, 1997-2015, used in this study. Price of wind turbine varies by producer and size. Here the lowest price available is used. Cheapest wind turbines are produced in China (Figure 8).

Description of all variables, data sources and summary statistics are presented in Table 3.

\subsection{Estimation strategy: panel unit root and panel cointegration tests}

Since our data sample is panel time-series data, it is necessary to test variables for the presence of a unit root (nonstationarity). For this panel data set with a large number of panels (countries, $N=106$ ) and a small number of time periods (years, $T=18$ ), two panel unit root tests are suitable to identify the presence of unit root, Harris-Tsavalis test (Harris and Tzavalis, 1999) and Im-Pesaran-Shin test (Im, et al., 2003). The demean is included in panel unit root tests to subtract cross-sectional means, as is necessary when there is a crosssectional dependence, which is possible in panel time-series data. The presence of crosssectional dependence is confirmed by the Pesaran CD test (Pesaran, 2004). The need to include time trend in panel unit root tests is identified by the significance of time trend in fixed effect estimation. Both panel unit root tests show the presence of unit root in wind energy and $g d p$, while $c o 2$ is stationary (Table 4). Nonstationarity of renewable energy generation is supported by a careful analysis in time series properties of the renewable energy diffusion process by Basher et al. (2015)

Since the dependent variable and one independent variable are nonstationary, there is a possibility of cointegration (i.e. long-run relationship) between them. Two cointegration tests, Kao test (Kao, 1999) and Westerlund test (Westerlund, 2005), are applied. Both cointegration tests strongly reject the null hypothesis of no cointegration in a favour of the alternative hypothesis of cointegration in all panels (Table 5). The number of lags for the Kao (1999) test is identified using the Hannan and Quinn information criterion (HQIC; Hannan and Quinn, 1979).

This study identifies the suitable estimation strategy based on data properties. The presence of cointegration (long-run relationship) between wind energy production and GDP is 
identified. The Mean Group (MG) estimation (Pesaran and Smith, 1995) is applied, because MG estimation allows for heterogeneous slope coefficients across countries and correlation across panel members (cross-section dependence) (Pesaran and Smith, 1995). First differences are used to correct for nonstationarity. The stationarity of variables in first differences is checked using the above unit root tests.

\section{Findings and discussion}

The results provide empirical evidence of the impact of different policy instruments on wind energy production, which is measured as a share in total electricity generation from all sources (Table 6). Each policy instrument measure is presented in a separate column. The first column of Table 6 "Existence" shows the impact of policy instrument existence, policy variables are measured as dummy variables which equal one if policy exists and zero otherwise. The second column of Table 6 "Experience" shows the impact of experience with policy instrument, policy variables are measured as the number of years of existence of each policy instrument. The third column of Table 6 "Change" shows the impact of changes of each policy instrument, policy variables are measured as the number of times policy instrument was changed, one when policy instrument was introduced and zero before policy instrument was set.

\section{Control variables}

The results show no impact of wind turbine price, coal price and GDP on wind energy production. The impact of $\mathrm{CO} 2$ emission on wind energy production is negative. This means that greater $\mathrm{CO} 2$ emissions do not lead to greater renewable energy production, and even have negative effect. Although this result is unexpected, it is consistent with (Marques et al., 2010; Zhao et al., 2013). Zhao, et al. (2013) explain this negative relationship using the argument that social pressure for better environment does not necessarily affect the decision process of choosing renewable energy sources instead of non-renewable (Marques, et al., 2010). Also this could be due to a causality problem. It is possible that wind energy production reduced $\mathrm{CO} 2$ emission, thus resulting in a negative relationship.

\section{Policy variables}

The results show that two policy instruments have statistically significant positive impact on wind energy production: taxes and strategic planning. However, the results show that the impact of policy instruments depends on its measures.

The results show that tax incentives promote wind energy production when it is measured as a dummy variable. This means that its impact only depends on the existence of the policy instrument, and does not depend on the number of years the policy instrument has existed or the number of changes.

Strategic planning also promotes wind energy production, but only when measured as one of a number of policy instrument changes. This means that its impact increases with a number of policy instrument changes.

None of policy variables have impact on wind energy production when measured as a number of years during which policy exists. 
Interactions of each of three policy measures with both noneconomic policies and with government effectiveness are not significant. There is no evidence that impact of fiscal policies is conditional on the existence of other policies or on government effectiveness. Results of these estimations are not included in this paper, but can be obtained from the authors on request.

\section{Conclusions, limitation and further research}

The existing literature highlights the importance of combination of policies, however the literature does not provide efficient combinations of policies. This paper develops and tests the model which enables to pick up the desired blend of policy instruments in the field of renewables and more specifically in wind power generation. Identifying a blend of policies is challenging as there is no identical combination of policies for all countries drawing on the study patterns. The efficient combination of policies depends on countries' needs, formal and informal institutions, environmental innovation, ecosystem, stakeholders and available resources (Sawin and Flavin, 2006).

This study demonstrates that production of new policies in order to facilitate renewables and more specifically wind power generation may not be an outdated approach. To better understand those challenges and answer our research question we used the effectiveness of renewable energy policy instruments, which was measured using five measures of policy variables: existence, experience, changes, implementation and a combination of policy instruments. Addressing the issue of what specific instruments could be in place and whether they are effective, using the data from five various international data sources over 1997-2014, sheds more light on policy development.

In relation to the introduction of potentially new policies, it appears that the effectiveness depends on strategic planning and tax incentives, which aim to incentivise wind energy production. Policy makers, government officials, companies and researchers therefore can draw on these results to justify the use of these two instruments in their policies, research and lobby. Policy-makers, when using renewable energy policy instruments, need to bear in mind that changes in wind energy production depend on the existence of these two policy instruments. Strategic planning for enterprises, with appropriate training, emerges as an important instrument to promote wind energy production.

Unlike taxes, the impact of strategic planning increases with the number of policy changes. The effectiveness of strategic planning benefits from policy changes. This is good news, meaning that the effectiveness of policy instrument can be improved with policy changes, "learning by doing". Policy changes allow countries to tailor policy instruments to countryspecific conditions.

To come to these policy recommendations we utilize the multi-source data on energy policy instruments on electricity generation by wind power, using data from 106 countries over the 18-year period (1997-2014). Our motivation derives from prior empirical studies, which attempted to uncover the determinants of renewable energy production/consumption, including the impact of policy instruments. This study focuses on one renewable energy source, wind turbines. Estimation by one renewable energy source is strategic as it offers the 
advantage of including the price of the renewable energy source and policy instruments which aim to affect specific renewable energy. Policy instruments are those which target to affect electricity generation by wind turbines rather than through the inclusion of general renewable energy policy instruments.

The principal conclusions from this study are as follows. First, this study demonstrates that two policy instruments have statistically significant positive impact on wind energy production: that is, tax policy (including tax reliefs) and strategic planning.

Second, the changes in wind energy production depend on the existence of tax incentives, and do not depend on the time frame of the policy instrument or the number of times the policy instrument (taxes) were changed. We contend that the impact of taxes depends on the existence of the policy instrument, and does not depend on the number of years tax incentives exist, number of tax changes, quality of implementation and combination with other noneconomic policy instruments.

Third, strategic planning appears to be an important instrument to promote wind energy production. Interestingly, the impact of this instrument increases with a number of other policy instrument changes.

Interactions of various policy measures with both noneconomic policies and government effectiveness were not found to have a significant effect on wind energy production

This paper makes two contributions: empirical and methodological. Its empirical contribution is into clean-energy and environmental policy literature by identifying the policies which are more conducive to the development of wind energy. In particular, out of a number of policy instruments used to support wind energy (such as strategic planning, grants and subsidies, taxes, feed-in tariffs/premiums, R\&D, direct investment, codes and standards, green certificates, loans), changes in strategic planning and taxes were found to be the most effective.

The methodological contribution of this study is in combining dataset across 106 counties over 1997-2014 from five sources (BP, 2017; IEA, 2017; IEA and IRENA, 2017; IRENA, 2017; Kaufmann, et al., 2010) and applying it in the context of renewable energy to answer our major research question: What are the most effective renewable energy policy instruments and how do they facilitate wind energy production?

The findings of this study could be applied to various forms of energy and is generalizable to other energy areas. Although it is primarily focused on wind energy production and policy, the same methodology could apply to other renewable energy sources, such as solar, geothermal, wave, tidal, hydro and biomass. This will considerably increase the implications for all ecosystem stakeholders and other industries. This study informs policy makers across developed and developing countries, international energy associations, institutions and other stakeholders on how we could lead the way to more effective governance of renewables, using the example of wind energy.

For example, by discussing the extent to which incentives could be applied within each type of instrument, barriers to policy instruments targeting the expansion of the use of the renewables are also discussed. These barriers are the adoption of new technologies which are used to generate renewable energy, and understanding the boundaries and maturity level of technology, as well as the process of commercialization of knowledge in market. 
The reason why other policy instruments have no impact on wind energy can be due to the absence of other policies necessary to promote renewable energy production. Renewable energy policies could be necessary but not sufficient to promote intermittent energy production. Wind turbines, along with solar panels, are often called variable renewable energy sources or intermittent generation sources. Intermittent power output fluctuates depending on the weather and environmental factors (Zerrahn, 2017), but not on consumers' energy demand. Moreover wind energy, as well as solar, has zero marginal costs (Zerrahn, 2017). Excess supply of renewable electricity, for example due to strong wind, can reduce electricity price even to a negative number (Starn, 2017), because electricity demand and supply must be balanced in power systems, while switching wind turbines off could be costly (Mendick, 2015 and Follett, 2016). That is why intermittent generation sources can impose a significant burden on the power systems. When renewable energy production exceeds energy demand, part of intermittent generation sources must be turned off ${ }^{1}$, reducing the production of renewable energy. The balancing gets harder the larger the share of intermittent energy sources (Zerrahn, 2017). Policies which can solve problems with intermittency are needed to promote intermittent energy production, such as subsidising energy storage as in Australia (Meyer, 2015) or investment in RD\&D of energy storage as in the UK (Bayar, 2017). Such policies will provide the necessary flexibility to accommodate variable wind energy supply in power systems.

Subsequent research will require testing a more nuanced relationship between the type of policy instrument and institutional environment in countries aiming to support and incentivise the use of alternative energy through a number of tools. It is important to understand the role played by each of the instruments in the level of adoption of wind energy use and the role of local and national institutions in moderating the adoption level. For example, variance decomposition could further explain the role of each policy instrument as compared to the others. Although our findings demonstrate which policy instruments work and which do not, further cross-country analyses would be of benefit by grouping countries in regions and estimating the marginal effect of each instrument on renewable energy by region. There are clear regional effects related to quality of environment, environmental regulation, formal and informal institutions which play an important role in adapting the use of renewable sources. For example, for the developing economies the importance of certain policy instruments such as availability of financial capital and legislation would work differently as an incentive compared to developed countries. Special attention should be given to the reasons behind this and to how policy makers and firms involved in production and use of energy will respond to changes in regulation. By analysing the geographical differences between environmental policy instruments and the adoption of renewable energy, further research may be able to better explain why, in other regions and innovation ecosystems, certain environmental policy instruments do not work and the reasons for the variance of distribution of the effects on wind power generation.

Further research could use cost-benefit approach and justify to what extent it is feasible, desirable and viable (using these three important criteria) to increase energy generation using renewables, reducing carbon emissions and improving energy security (Carley, 2009 and Sawin and Flavin, 2006). The literature on environmental policy and adoption of technologies

\footnotetext{
${ }^{1}$ The turbines have to be shut down in the UK to keep supply and demand in the National grid balanced (Mendick, 2015). The wind farm owners then receive compensation payments for not producing electricity.
} 
still searches for answers on the effectiveness of policies targeting to improve use of renewable energy, applying different empirical methods and data samples. 
References

Ackermann, T., Andersson, G. and Söder, L. (2001) 'Overview of government and market driven programs for the promotion of renewable power generation', Renewable Energy, Vol. 22 No.1, pp.197-204.

Aguirre, M. and Gbenga, I. (2014) 'Determinats of renewable energy growth: A global sample analysis’, Energy Policy, Vol. 69, pp.374-384.

Baldwin, E., Carley, S., Brass, J.N. and MacLean, L.M. (2017) 'Global Renewable Electricity Policy: A Comparative Policy Analysis of Countries by Income Status', Journal of Comparative Policy Analysis: Research and Practice, Vol. 19 No. 3, pp.277-298.

Basher, S.A., Masini, A. and Aflaki, S. (2015) 'Time series properties of the renewable energy diffusion process: Implications for energy policy design and assessment' Renewable and Sustainable Energy Reviews, Vol. 52, pp.1680-1692.

Bayar, T. (2017) 'UK to Invest \$320M in Energy Storage R\&D', Renewable Energy World, 25 July 2017, http://www.renewableenergyworld.com/articles/2017/07/uk-to-invest-320m-inenergy-storage-r-d.html (Accessed 7 December 2017).

Beck, F. and Martinot, E. (2004) 'Renewable energy policies and barriers', Encyclopedia of energy, Vol. 5 No. 7, pp.365-383.

Bloomberg New Energy Finance (BNEF) (2017) '2016 Wind Turbine Price Index’

British Petroleum (BP), 2017. BP Statistical review of world energy June $2017,66^{\text {th }}$ ed., BP, London.

Byrnes, B., Jones, C., and Goodman, S. (1999) 'Contingent valuation and real economic commitments: evidence from electric utility green pricing programmes', Journal of Environmental Planning and Management, Vol. 42 No.2, pp.149-166.

Carley, S. (2009) 'State renewable energy electricity policies: An empirical evaluation of effectiveness'. Energy policy, Vol. 37 No. 8, pp. 3071-81.

Carley, S., Baldwin, E., MacLean, L.M. and Brass, J.N. (2016) 'Global Expansion of Renewable Energy Generation: An Analysis of Policy Instruments', Environmental and Resource Economics, Vol. 68 No. 2, pp.1-44.

Chatterjeea K.S., Dwivedib, P Senguptac, A. (2013) Promotion of Wind and Solar Energy through Renewable Energy Certificate System: Lessons from Renewable Obligation Certificate, United Kingdom experience for India, http://siteresources.worldbank.org/FINANCIALSECTOR/Resources/000_India_Wind_and_S olar_Industry_9_10_2013.pdf (Accessed 7 December 7 2017).

Del Río, P., and Mir-Artigues, P. (2014) 'Combinations of support instruments for renewable electricity in Europe: a review', Renewable and Sustainable Energy Reviews, Vol. 40, pp.287-295.

Deyette, J., Clemmer, S., and Donovan, D. (2003) Plugging in Renewable Energy: Grading the States, Union of Concerned Scientists, Cambridge, MA. 
Follett, A., 2016. Germany Paid Wind Turbines \$548 Million To Sit Idle. The Daily Caller, 29 April 2016. http://dailycaller.com/2016/04/29/germany-paid-wind-turbines-548-millionto-sit-idle (Accessed 7 December 2017).

Haas, R., Eichhammer, W., Huber, C., Langniss, O., Lorenzoni, A., Madlener, R., Menanteau, P., Morthorst, P.E., Martins, A., Oniszk, A. and Schleich, J. (2004) 'How to promote renewable energy systems successfully and effectively’, Energy Policy, Vol. 32 No. 6, pp.833-839.

Hannan, E. J. and Quinn, B. G. (1979) 'The Determination of the order of an autoregression', Journal of the Royal Statistical Society, Series B, Vol. 41, pp.190-195.

Harris, R. D., and Tzavalis, E. (1999) 'Inference for unit roots in dynamic panels where the time dimension is fixed', Journal of econometrics, Vol. 91 No. 2, pp.201-226.

Im, K., Pesaran, M. and Shin, Y. (2003) 'Testing for unit roots in heterogeneous panels', Journal of Econometrics, Vol. 115 No. 1, pp.53-74.

International Energy Agency (IEA) and International Renewable Energy Agency (IRENA) (2017) Joint Policies and Measures database for Global Renewable Energy, https://www.iea.org/policiesandmeasures/renewableenergy (Accessed 7 December 2017).

International Energy Agency (IEA) (2017) World Energy Statistics and Balances Extended world energy balances, International Energy Agency, Paris.

International Renewable Energy Agency (IRENA) (2012) 'Evaluating Policies in Support of the Deployment of Renewable Power', IRENA Policy Brief http://www.irena.org/publications/2012/Oct/Evaluating-policies-in-support-of-thedeployment-of-renewable-power (Accessed 7 December 2017).

International Renewable Energy Agency (IRENA) (2017) Renewable Cost Database http://www.irena.org/costs (Accessed 7 December 2017).

Jacobsson, S., Bergek, A., Finon, D., Lauber, V., Mitchell, C., Toke, D. and Verbruggen, A. (2009) 'EU renewable energy support policy: Faith or facts?', Energy policy, Vol. 37 No. 6, pp.2143-2146.

Johnstone, N., Haščič, I. and Popp, D. (2010) 'Renewable energy policies and technological innovation: evidence based on patent counts', Environmental and resource economics, Vol. 45 No. 1, pp.133-155.

Kalyuzhnova, Y. (2017) 'Resource-rich countries, clean energy and volatility of oil prices', in Kalyuzhnova, Y. and Pomfret, R. (Eds.), Sustainable Energy in Kazakhstan: Moving to Cleaner Energy in a Resource-rich Country, Routledge, Oxon and New York, pp.7-17.

Kao, C. (1999) 'Spurious regression and residual-based tests for cointegration in panel data', Journal of econometrics, Vol. 90 No. 1, pp.1-44.

Karatayev, M., Hall, S., Kalyuzhnova, Y., and Clarke, M. L. (2016) 'Renewable energy technology uptake in Kazakhstan: Policy drivers and barriers in a transitional economy’, Renewable and Sustainable Energy Reviews, Vol. 66, pp.120-136. 
Kaufmann, D., Kraay, A. \& Mastruzzi, M. (2010) 'The Worldwide Governance Indicators: Methodology and Analytical Issues', Hague Journal on the Rule of Law, Vol. 3 No. 2 , pp.220-246.

Klein, A., Merkel, E., Pfluger, B., Held, A., Ragwitz, M., Resch, G., \& Busch, S. (2008) 'Evaluation of different feed-in tariff design options: Best practice paper for the International Feed-in Cooperation', Energy Economics Group \& Fraunhofer Institute Systems and Innovation Research http://www.feed-in-cooperation.org/wDefault_7/downloadfiles/research/Best_practice_Paper_3rd_edition.pdf (Accessed 7 December 2017).

Kousksou, T., Allouhi, A., Belattar, M., Jamil, A., El Rhafiki, T., Arid, A., and Zeraouli, Y. (2015) 'Renewable energy potential and national policy directions for sustainable development in Morocco', Renewable and Sustainable Energy Reviews, Vol. 47, pp.46-57.

Marques, A., Fuinhas, J. and Manso, J. (2010) 'Motivations driving renewable energy in European countries: A panel data approach', Energy policy, Vol.38 No.11, pp.6877-6885.

Menanteau, P., Finon, D. and Lamy, M.L. (2003) 'Prices versus quantities: choosing policies for promoting the development of renewable energy', Energy policy, Vol. 31 No. 8, pp.799812.

Mendick, R. (2015) 'Wind farms paid £1m a week to switch off', The Telegraph, 4 January 2015 http://www.telegraph.co.uk/news/earth/energy/windpower/11323685/Wind-farms-paid1m-a-week-to-switch-off.html (Accessed 7 December 2017).

Mendonca, M., Jacobs, D., \& Sovacool, B. K. (2009) Powering the green economy: The feedin tariff handbook, Routledge, London.

Menz, F.C. and Vachon, S. (2006) 'The effectiveness of different policy regimes for promoting wind power: Experiences from the states', Energy policy, Vol. 34 No.14, pp.17861796.

Pesaran, M. H. and Smith, P. R. (1995) 'Estimating long-run relationships from dynamic heterogeneous panels', Journal of Econometrics, Vol. 68 No. 1, pp.79-113.

Pesaran, M. (2004) 'General Diagnostic Tests for Cross Section Dependence in Panels', IZA Discussion Papers, Vol.1240.

Polzin, F., Migendt, M., Täube, F. A., and von Flotow, P. (2015) 'Public policy influence on renewable energy investments-A panel data study across OECD countries', Energy Policy, Vol. 80, pp.98-111.

Romano, A. A., Scandurra, G., Carfora, A., and Fodor, M. (2017) 'Renewable investments: The impact of green policies in developing and developed countries', Renewable and Sustainable Energy Reviews, Vol. 68 Part I, pp.738-747.

Sawin, J. and Flavin, C. (2006) 'National policy instruments: Policy lessons for the advancement \& diffusion of renewable energy technologies around the world' in: Assmann, D., Laumanns, U. and Uh, D. (Eds.), Renewable Energy: A Global Review of Technologies, Policies and Markets, Earthscan, London and Sterling, pp.71-114. 
Starn, J. (2017) 'Germany set to pay customers for electricity usage as renewable energy generation creates huge power surplus’, Independent, 27 October 2017, http://www.independent.co.uk/environment/germany-grids-paying-electricity-customersrenewable-energy-power-surplus-wind-solar-generation-a8022576.html (Accessed 7 December 2017).

World Bank (WB) (2017) World Developments Indicators, The World Bank, Washington DC, http://data.worldbank.org/data-catalog/world-development-indicators (Accessed 7 December 2017).

Westerlund, J. (2005) 'New simple tests for panel cointegration', Econometric Reviews, Vol. 24 No. 3, pp.297-316.

Winkler, H. (2005) 'Renewable energy policy in South Africa: policy options for renewable electricity’, Energy Policy, Vol. 33 No. 1, pp.27-38.

Wiser, R. and Bolinger, M. (2017) 2016 Wind Technologies Market Report, US Department of Energy, Office of Energy Efficiency and Renewable Energy. August, https://energy.gov/sites/prod/files/2017/08/f35/2016_Wind_Technologies_Market_Report_0. pdf (Accessed 7 December 2017).

Zerrahn, A. (2017) 'Wind Power and Externalities', Ecological Economics, Vol. 141, pp.245260.

Zhao, Y., Tang, K. K., and Wang, L. L. (2013) 'Do renewable electricity policies promote renewable electricity generation? Evidence from panel data', Energy policy, Vol. 62, pp.887897. 


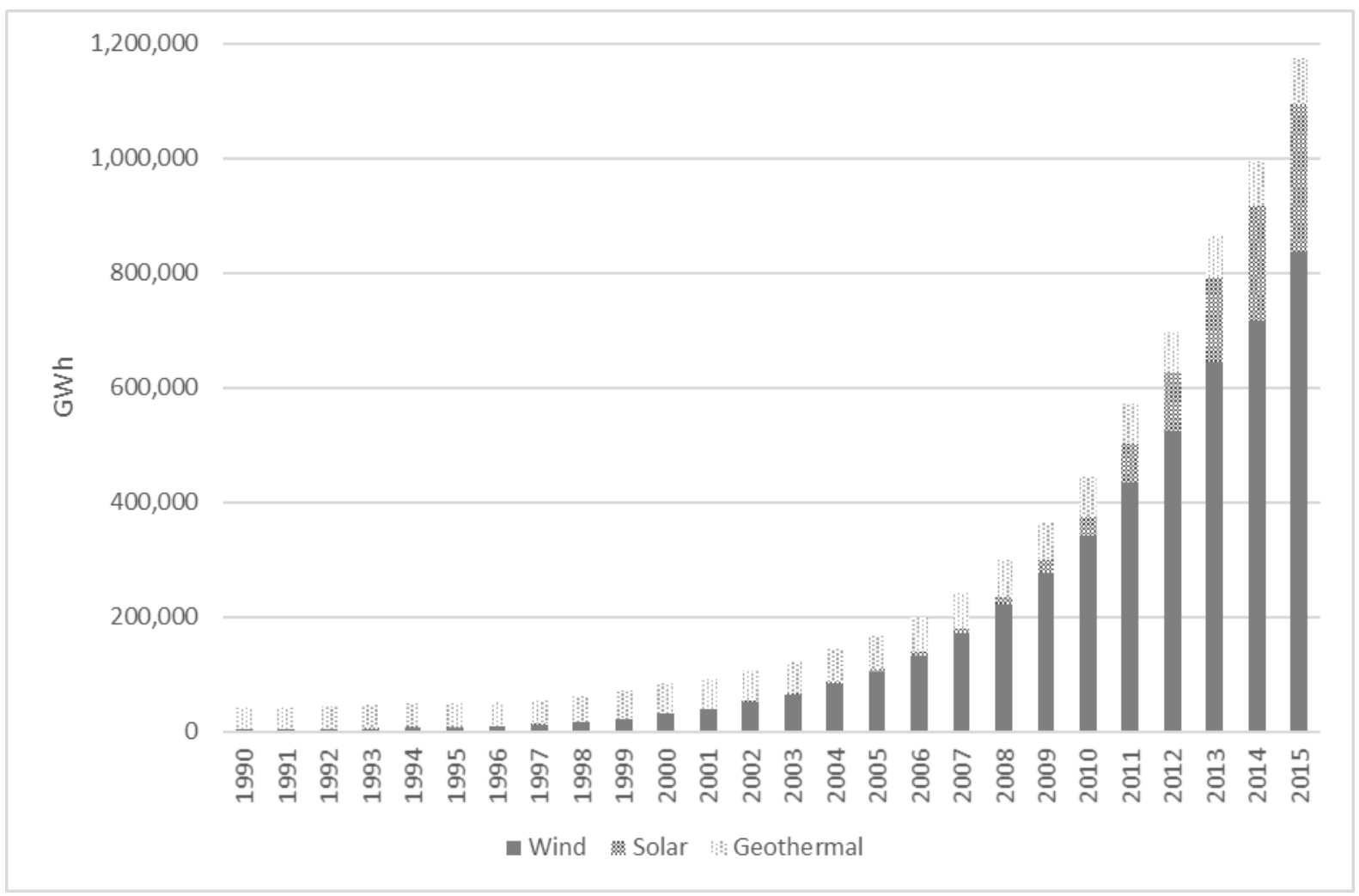

Figure 1 World electricity generation from renewable energy sources

Data source: IEA (2017)

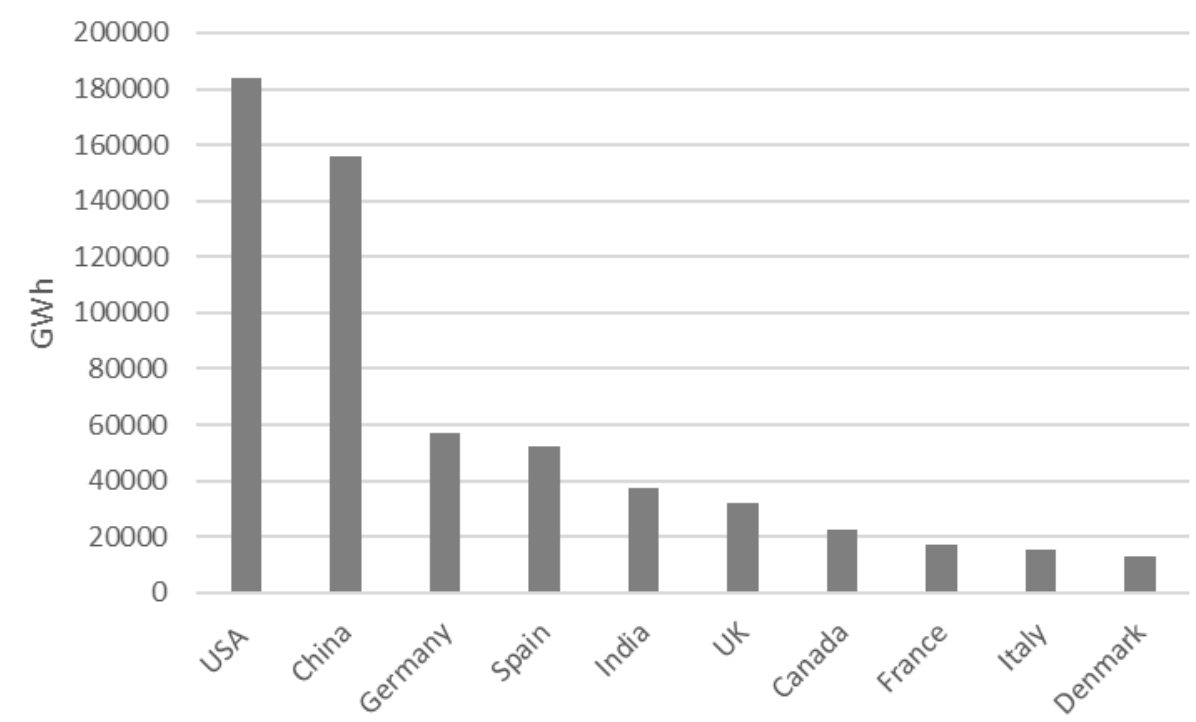

Figure 2 Top eleven wind energy producing countries in 2014

Data source: IEA (2017) 


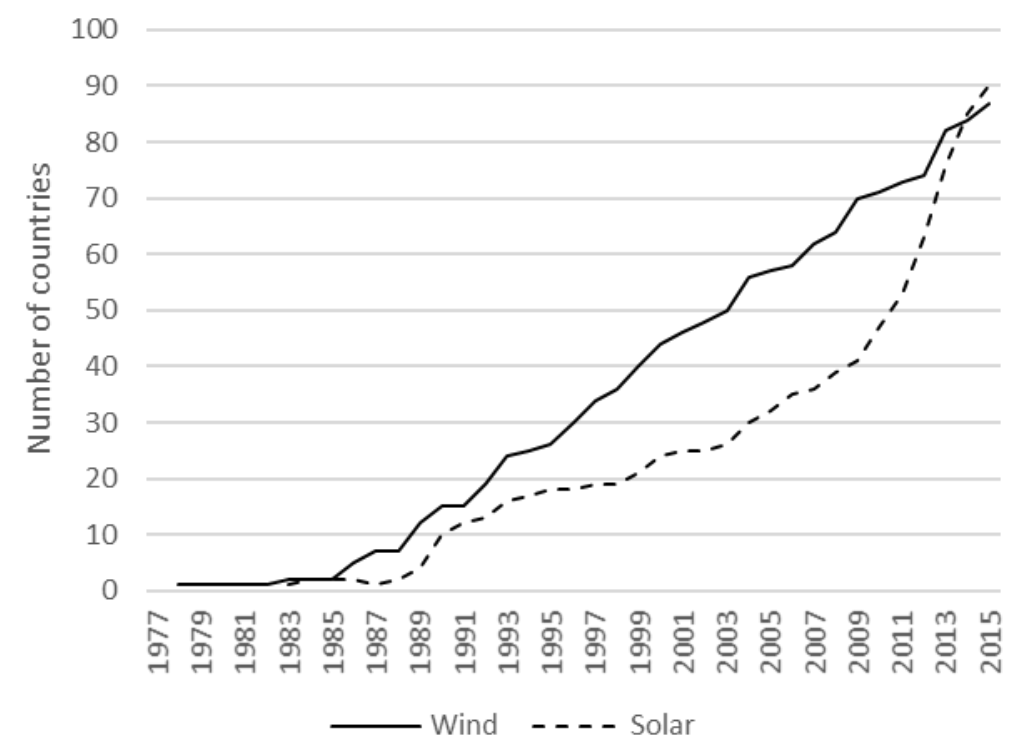

Figure 3 Number of countries producing wind and solar energy

Data source: IEA and IRENA (2017)

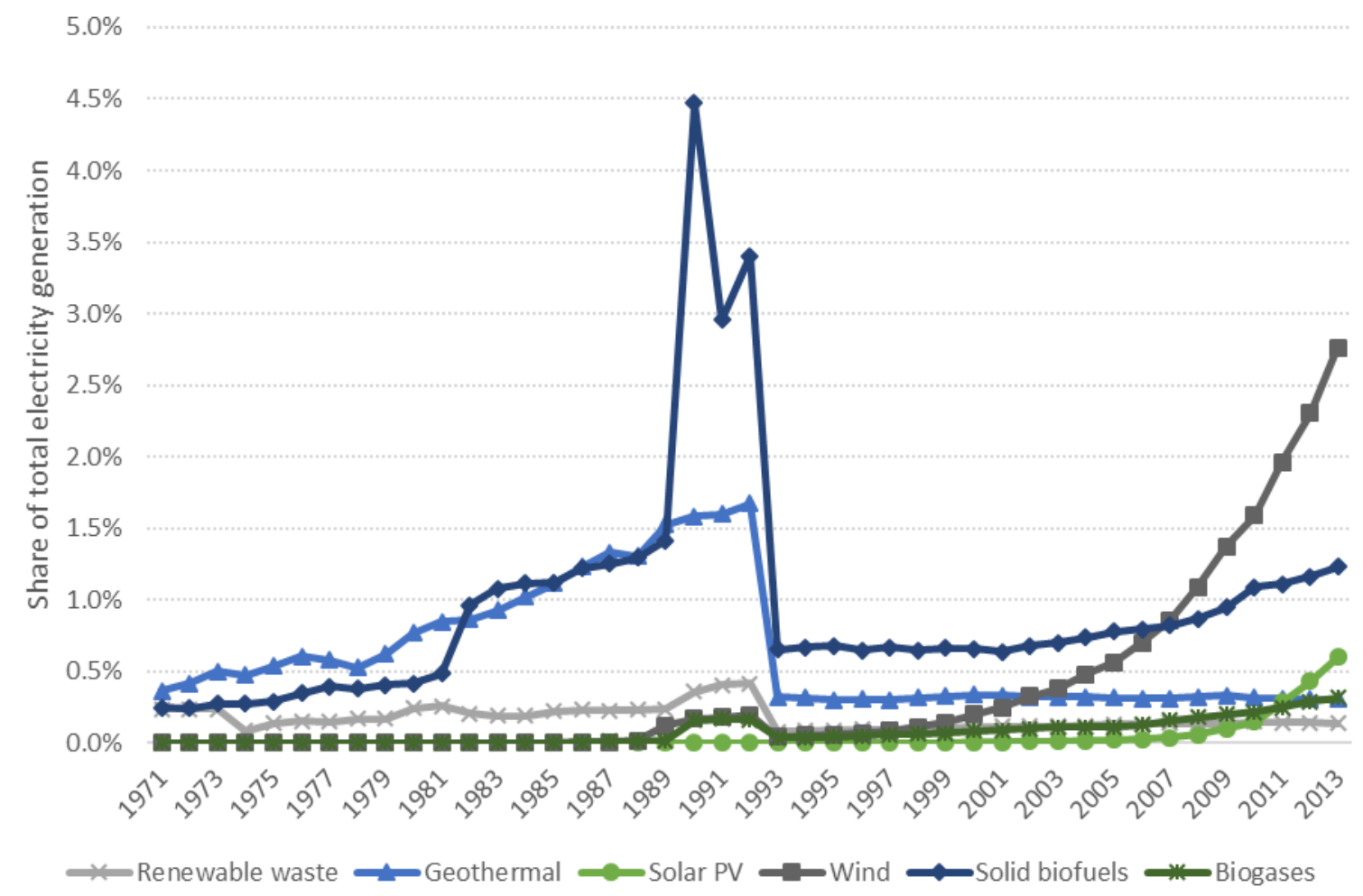

Figure 4 World electricity generation from renewable energy sources, \% of electricity generation from all sources

Data source: IEA (2017) 


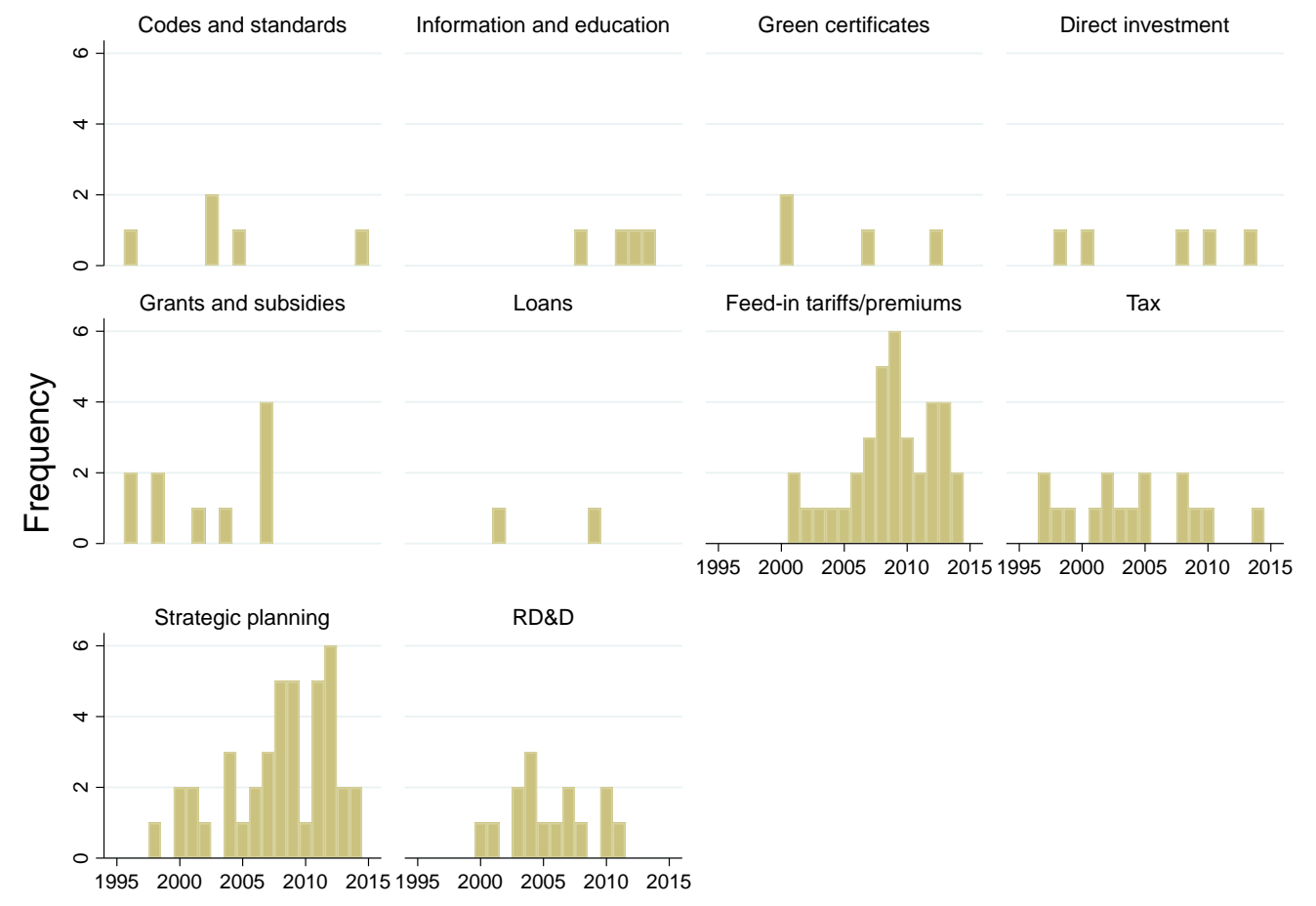

Figure 5 Number of countries that introduced policies between 1997 and 2014

Data Source: IEA and IRENA (2017)

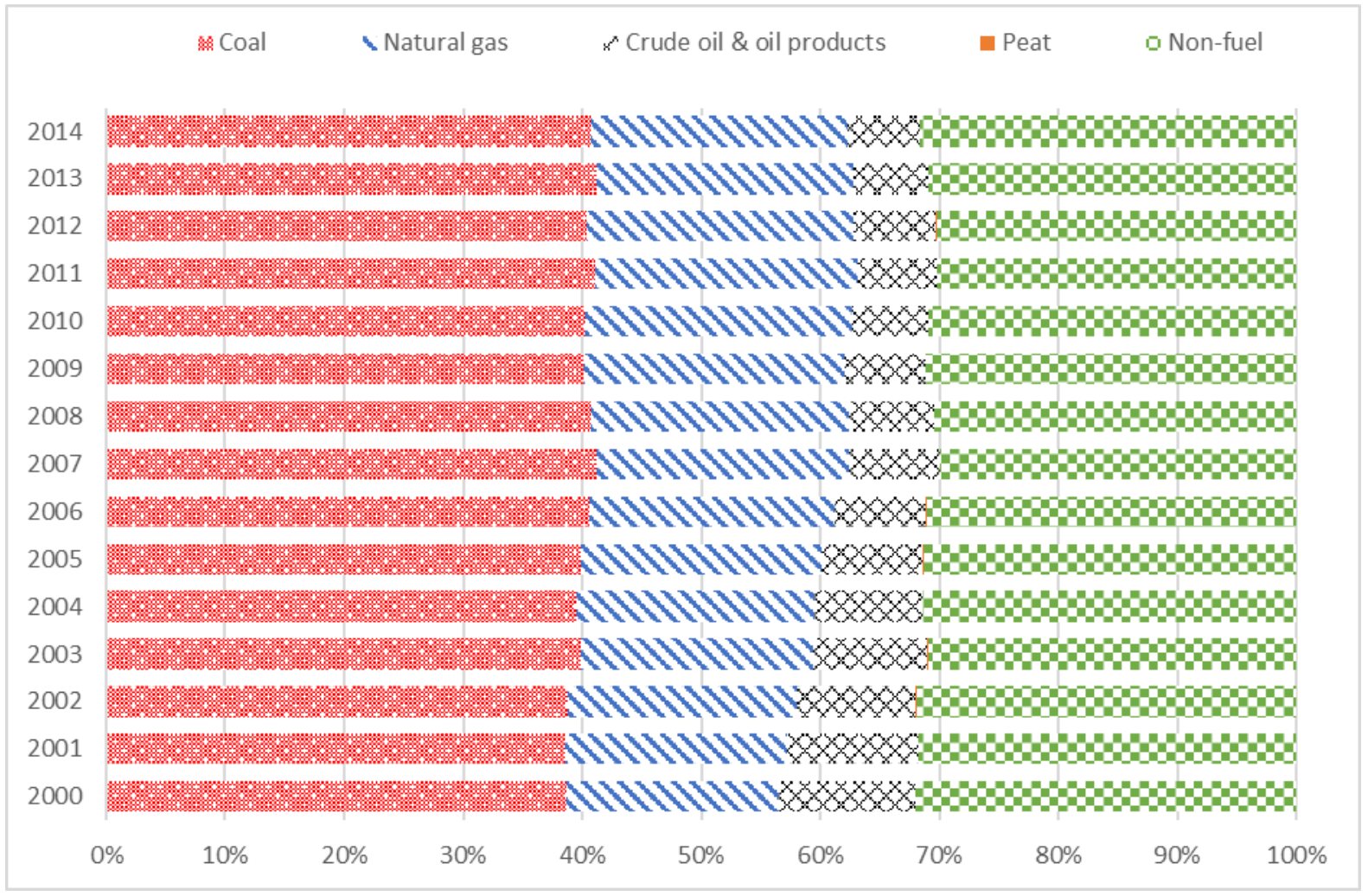

Figure 6 Electricity generation by fuel

Source: IEA (2017) 


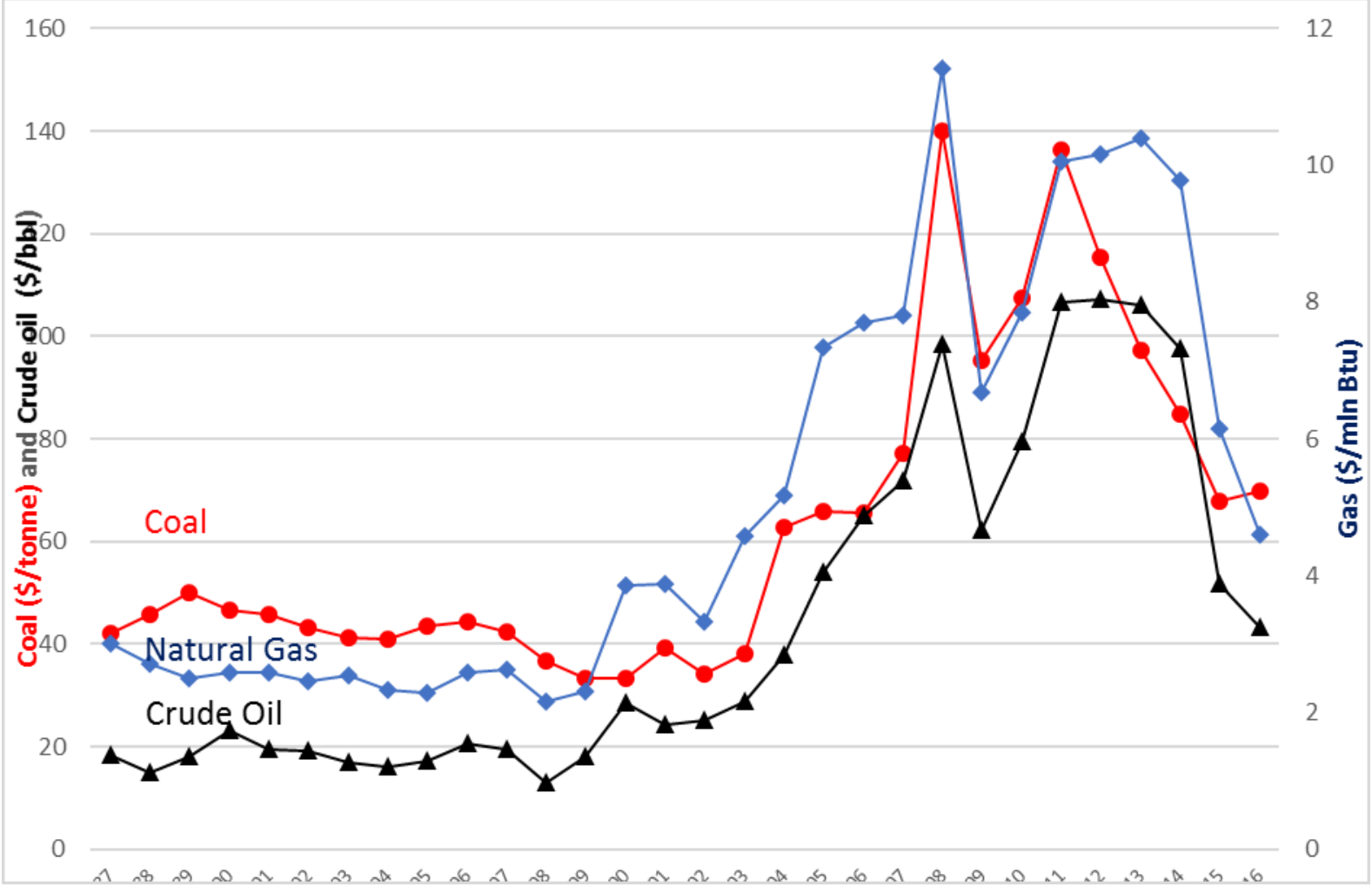

Figure 7 Prices of three major non-renewable electricity sources

Source: British Petroleum (2016)

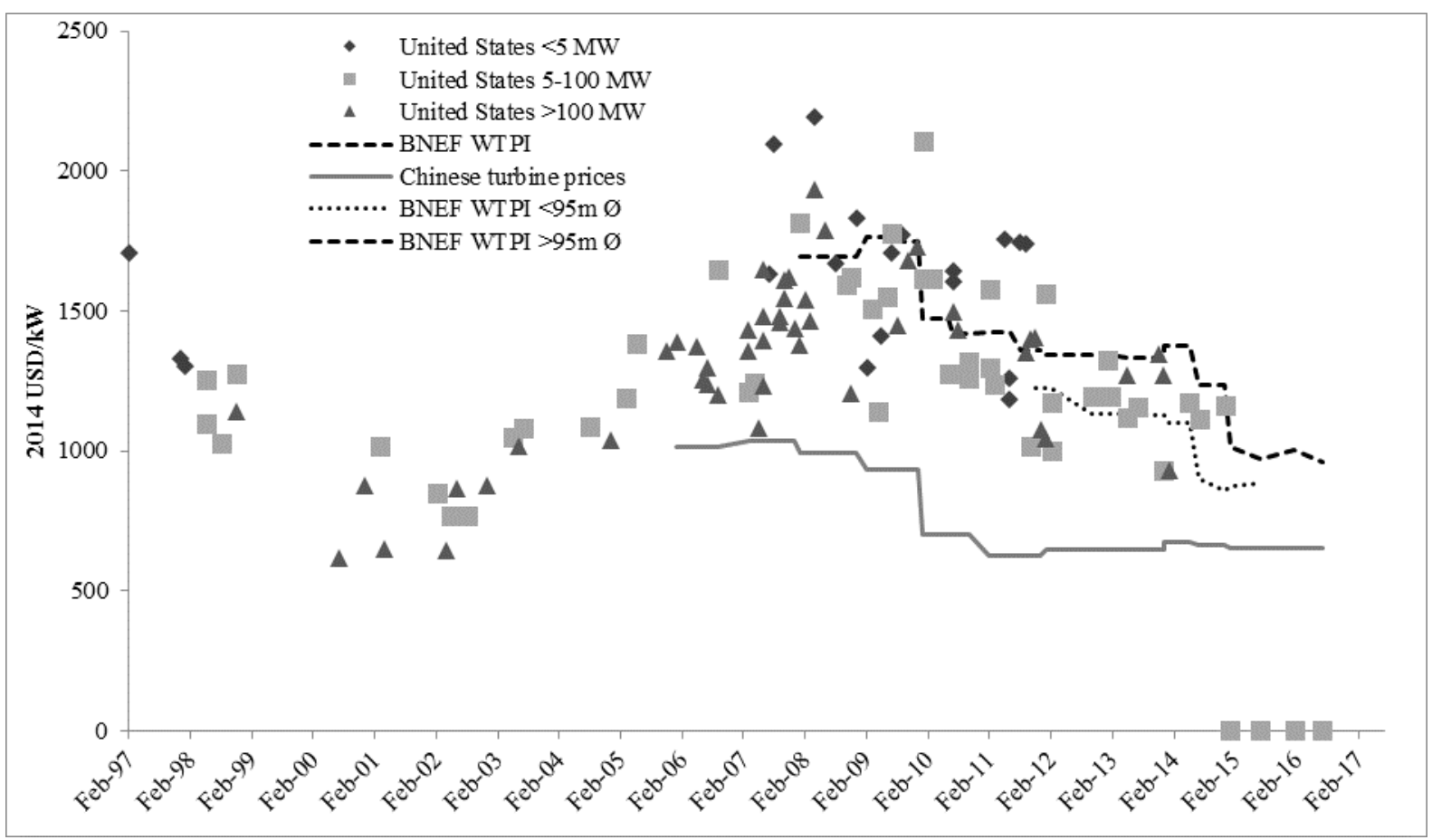

Figure 8 Price of wind turbines

Source: Wiser and Bollinger (2017); Bloomberg New Energy Finance (BNEF) (2017) and IRENA (2017) 
Table 1 Summary of empirical results of the impact of renewable energy policy instruments

\begin{tabular}{|c|c|c|c|c|}
\hline Studies & $\begin{array}{l}\text { Dependent } \\
\text { variable }\end{array}$ & Positive impact & Negative impact & No impact \\
\hline $\begin{array}{l}\text { Aguirre \& } \\
\text { Gbenga, } 2014\end{array}$ & $\begin{array}{l}\text { Renewable } \\
\text { energy, share of } \\
\text { energy supply }\end{array}$ & & $\begin{array}{l}\text { Fiscal and } \\
\text { financial } \\
\text { Voluntary }\end{array}$ & $\begin{array}{l}\text { Investment } \\
\text { FIT } \\
\text { Grants and } \\
\text { subsidies } \\
\text { Certificates } \\
\text { Information and } \\
\text { education } \\
\text { Loans } \\
\text { RD\&D } \\
\text { Regulatory }\end{array}$ \\
\hline $\begin{array}{l}\text { Baldwin et al. } \\
\text { (2017) }\end{array}$ & $\begin{array}{l}\text { Renewable } \\
\text { energy } \\
\text { generation }\end{array}$ & $\begin{array}{l}\text { FIT } \\
\text { RPS } \\
\text { Subsidies }\end{array}$ & & $\begin{array}{l}\text { FIT } \\
\text { Subsidies }\end{array}$ \\
\hline Carley (2009) & $\begin{array}{l}\text { Renewable } \\
\text { energy, share of } \\
\text { electricity } \\
\text { generation }\end{array}$ & $\begin{array}{l}\text { Subsidies } \\
\text { RPS }\end{array}$ & Taxes & \\
\hline Carley (2009) & $\begin{array}{l}\text { Renewable } \\
\text { electricity } \\
\text { generation }\end{array}$ & $\begin{array}{l}\text { Subsidies } \\
\text { RPS }\end{array}$ & Taxes & \\
\hline $\begin{array}{l}\text { Johnstone, et } \\
\text { al., } 2010\end{array}$ & $\begin{array}{l}\text { Patent } \\
\text { applications in } \\
\text { wind energy }\end{array}$ & $\begin{array}{l}\text { RD\&D } \\
\text { Certificates }\end{array}$ & FIT & $\begin{array}{l}\text { Investment } \\
\text { Taxes } \\
\text { Voluntary }\end{array}$ \\
\hline $\begin{array}{l}\text { Zhao et al. } \\
\text { (2013) }\end{array}$ & $\begin{array}{l}\text { Wind energy, } \\
\text { share of } \\
\text { electricity } \\
\text { generation }\end{array}$ & $\begin{array}{l}\text { FIT } \\
\text { Investment }\end{array}$ & $\begin{array}{l}\text { Voluntary } \\
\text { Certificates } \\
\text { Quota }\end{array}$ & $\begin{array}{l}\text { Taxes } \\
\text { Certificates }\end{array}$ \\
\hline
\end{tabular}

Note: FIT - feed-in tariff, RPS - renewable portfolio standards.

Table 2 Renewable energy policy instruments

\begin{tabular}{|c|c|c|c|c|}
\hline \multirow[t]{2}{*}{ Category } & \multirow[t]{2}{*}{ Subcategory } & \multirow[t]{2}{*}{ Policy instrument } & \multicolumn{2}{|c|}{$\begin{array}{c}\text { Number of electricity } \\
\text { policy changes till } 2014\end{array}$} \\
\hline & & & $\begin{array}{l}\text { Wind } \\
\text { energy }\end{array}$ & $\begin{array}{l}\text { Renewable } \\
\text { energy }\end{array}$ \\
\hline \multirow[t]{8}{*}{ Economic } & Direct investment & $\begin{array}{l}\text { Funds to subnational } \\
\text { governments }\end{array}$ & 0 & 8 \\
\hline & & $\begin{array}{l}\text { Infrastructure } \\
\text { investments }\end{array}$ & 16 & 40 \\
\hline & & Procurement rules & 4 & 5 \\
\hline & & RD\&D funding & 2 & 6 \\
\hline & $\begin{array}{l}\text { Fiscal/financial } \\
\text { incentives }\end{array}$ & $\begin{array}{l}\text { Feed-in } \\
\text { tariffs/premiums }\end{array}$ & 85 & 183 \\
\hline & & Grants and subsidies & 62 & 133 \\
\hline & & Loans & 11 & 30 \\
\hline & & $\begin{array}{l}\text { Taxes including tax } \\
\text { relief }\end{array}$ & 38 & 78 \\
\hline
\end{tabular}




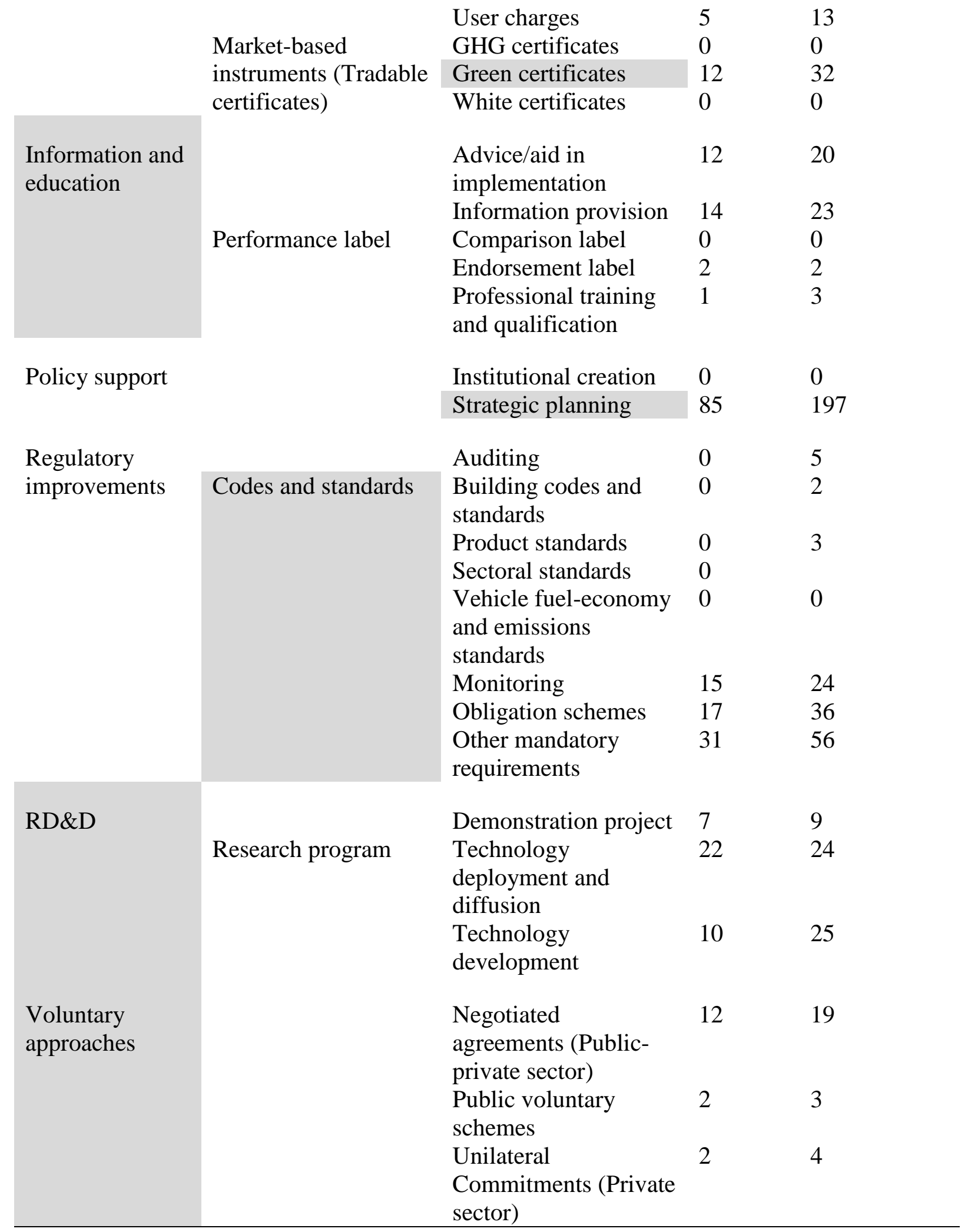

Data source: IEA and IRENA (2017)

Note: Policy instruments which are included in this study are shaded in grey. 
Table 3 Summary statistics

\begin{tabular}{|c|c|c|c|c|c|c|}
\hline Variable & Description & Source & $\begin{array}{c}\text { Mea } \\
\mathrm{n}\end{array}$ & s.d. ${ }^{2}$ & $\begin{array}{c}\mathrm{Mi} \\
\mathrm{n}\end{array}$ & Max \\
\hline $\begin{array}{l}\text { Wind } \\
\text { energy }\end{array}$ & $\begin{array}{l}\text { Wind energy production, } \% \text { of } \\
\text { electricity generation from all } \\
\text { sources }\end{array}$ & $\begin{array}{l}\text { IEA } \\
(2017)\end{array}$ & 0.91 & 2.94 & $\begin{array}{c}0.0 \\
0\end{array}$ & 40.64 \\
\hline $\mathrm{CO} 2$ & $\begin{array}{l}\text { CO2 emissions, kg per } 2010 \text { US\$ of } \\
\text { GDP }\end{array}$ & $\begin{array}{l}\text { WB } \\
(2017)\end{array}$ & 0.58 & 0.61 & $\begin{array}{c}0.0 \\
6\end{array}$ & 6.44 \\
\hline$G D P$ & GDP per capita, constant 2010 USD & $\begin{array}{l}\text { WB } \\
(2017)\end{array}$ & $\begin{array}{c}15,7 \\
67.0 \\
0\end{array}$ & $\begin{array}{c}19,8 \\
81.0 \\
0\end{array}$ & $\begin{array}{c}18 \\
6.7 \\
0\end{array}$ & $\begin{array}{l}111,9 \\
68.00\end{array}$ \\
\hline Coal price & $\begin{array}{l}\text { Average world coal price, } \\
\text { USD/tonne }\end{array}$ & BP (2017) & $\begin{array}{c}72.4 \\
8\end{array}$ & $\begin{array}{c}35.1 \\
1\end{array}$ & $\begin{array}{l}33 . \\
24\end{array}$ & $\begin{array}{c}139.9 \\
0\end{array}$ \\
\hline $\begin{array}{l}\text { Wind } \\
\text { turbine } \\
\text { price }\end{array}$ & Lowest wind turbine price, USD/kW & $\begin{array}{l}\text { IRENA } \\
(2017)\end{array}$ & $\begin{array}{c}955 . \\
60\end{array}$ & $\begin{array}{c}275 . \\
40\end{array}$ & $\begin{array}{c}61 \\
9.8 \\
0\end{array}$ & $\begin{array}{l}1,706 \\
.00\end{array}$ \\
\hline \multicolumn{7}{|c|}{ Policy variables measuring policy existence } \\
\hline $\begin{array}{l}\text { Grants and } \\
\text { subsidies }\end{array}$ & $\begin{array}{l}\text { Equals one if policy exists and zero } \\
\text { otherwise }\end{array}$ & \multirow{11}{*}{$\begin{array}{l}\text { IEA/ } \\
\text { IRENA } \\
(2017)\end{array}$} & 0.08 & 0.28 & 0 & 1 \\
\hline $\begin{array}{l}\text { Informatio } \\
n \text { and } \\
\text { education }\end{array}$ & $\begin{array}{l}\text { Equals one if policy exists and zero } \\
\text { otherwise }\end{array}$ & & 0.04 & 0.20 & 0 & 1 \\
\hline $\begin{array}{l}\text { Green } \\
\text { certificates }\end{array}$ & $\begin{array}{l}\text { Equals one if policy exists and zero } \\
\text { otherwise }\end{array}$ & & 0.04 & 0.19 & 0 & 1 \\
\hline $\begin{array}{l}\text { Direct } \\
\text { investment }\end{array}$ & $\begin{array}{l}\text { Equals one if policy exists and zero } \\
\text { otherwise }\end{array}$ & & 0.08 & 0.27 & 0 & 1 \\
\hline $\begin{array}{l}\text { Grants and } \\
\text { subsidies }\end{array}$ & $\begin{array}{l}\text { Equals one if policy exists and zero } \\
\text { otherwise }\end{array}$ & & 0.16 & 0.37 & 0 & 1 \\
\hline Loans & $\begin{array}{l}\text { Equals one if policy exists and zero } \\
\text { otherwise }\end{array}$ & & 0.04 & 0.18 & 0 & 1 \\
\hline $\begin{array}{l}\text { Feed-in } \\
\text { tariffs/pre } \\
\text { miums }\end{array}$ & $\begin{array}{l}\text { Equals one if policy exists and zero } \\
\text { otherwise }\end{array}$ & & 0.16 & 0.37 & 0 & 1 \\
\hline Taxes & $\begin{array}{l}\text { Equals one if policy exists and zero } \\
\text { otherwise }\end{array}$ & & 0.14 & 0.35 & 0 & 1 \\
\hline $\begin{array}{l}\text { Strategic } \\
\text { planning }\end{array}$ & $\begin{array}{l}\text { Equals one if policy exists and zero } \\
\text { otherwise }\end{array}$ & & 0.20 & 0.40 & 0 & 1 \\
\hline$R \& D$ & $\begin{array}{l}\text { Equals one if policy exists and zero } \\
\text { otherwise }\end{array}$ & & 0.08 & 0.27 & 0 & 1 \\
\hline $\begin{array}{l}\text { Voluntary } \\
\text { approache } \\
S\end{array}$ & $\begin{array}{l}\text { Equals one if policy exists and zero } \\
\text { otherwise }\end{array}$ & & 0.04 & 0.19 & 0 & 1 \\
\hline \multicolumn{7}{|c|}{ Policy variables measuring policy experience } \\
\hline $\begin{array}{l}\text { Grants and } \\
\text { subsidies }\end{array}$ & Number of years policy exists & $\begin{array}{l}\text { IEA/ } \\
\text { IRENA }\end{array}$ & 0.54 & 2.26 & 0 & 19 \\
\hline $\begin{array}{l}\text { Informatio } \\
n \text { and }\end{array}$ & Number of years policy exists & $(2017)$ & 0.28 & 1.77 & 0 & 20 \\
\hline
\end{tabular}

${ }^{2}$ Standard deviation 
education

Green Number of years policy exists certificates

Direct Number of years policy exists investment

Grants and Number of years policy exists subsidies

Loans Number of years policy exists

Feed-in Number of years policy exists tariffs/pre

miums

Taxes Number of years policy exists

Strategic Number of years policy exists planning

$R D \& D$

Number of years policy exists

Voluntary Number of years policy exists approache

$\begin{array}{llll}0.22 & 1.31 & 0 & 13\end{array}$

$\begin{array}{llll}0.44 & 2.03 & 0 & 20\end{array}$

$\begin{array}{llll}1.37 & 4.46 & 0 & 40\end{array}$

$\begin{array}{llll}0.25 & 1.77 & 0 & 24\end{array}$

$\begin{array}{llll}0.36 & 1.40 & 0 & 15\end{array}$

$\begin{array}{llll}1.15 & 3.93 & 0 & 36\end{array}$

$\begin{array}{llll}1.04 & 2.90 & 0 & 21\end{array}$

$\begin{array}{llll}0.58 & 2.90 & 0 & 34\end{array}$

$\begin{array}{llll}0.22 & 1.37 & 0 & 15\end{array}$ $S$

Policy variables measuring policy changes

Grants and

subsidies Number of policy changes

Informatio

$n$ and

education Number of policy changes

Green Number of policy changes

certificates

Direct Number of policy changes

investment

Grants and Number of policy changes subsidies

Loans Number of policy changes

Feed-in Number of policy changes

tariffs/pre

miums

Tax refief Number of policy changes

and taxes

Strategic planning

$R D \& D$

Voluntary

approache

$s$

Note: $\mathrm{N}=106$ and $\mathrm{T}=18$

Table 4 Panel unit root tests results

\begin{tabular}{lllllll}
\hline Variable & Trend & Demean & $\mathrm{N}$ & Harris-Tsavalis test & Im-Pesaran-Shin test & Result \\
\hline wind energy & yes & yes & 131 & 0.87 & 27.47 & Unit root \\
gdp & yes & yes & 125 & 0.79 & -0.11 & Unit root
\end{tabular}

IEA/

IRENA

(2017)

$\begin{array}{llll}0.07 & 0.42 & 0 & 5\end{array}$

$\begin{array}{llll}0.05 & 0.26 & 0 & 2\end{array}$

$\begin{array}{llll}0.10 & 0.40 & 0 & 4\end{array}$

$\begin{array}{llll}0.29 & 0.76 & 0 & 4\end{array}$

$\begin{array}{llll}0.04 & 0.23 & 0 & 3\end{array}$

$\begin{array}{llll}0.25 & 0.68 & 0 & 5\end{array}$

$\begin{array}{llll}0.19 & 0.53 & 0 & 4\end{array}$

$\begin{array}{llll}0.32 & 0.82 & 0 & 8\end{array}$

$\begin{array}{llll}0.13 & 0.48 & 0 & 4\end{array}$

$\begin{array}{llll}0.05 & 0.27 & 0 & 3\end{array}$ $\begin{array}{llll}0.12 & 0.45 & 0 & 4\end{array}$

Number of policy changes 
Note: $\mathrm{T}=18$. H0: all panels contain a unit root vs. H1: all panels are stationary in HT test and H1: some panels are stationary in IPS test

Table 5 Cointegration test results

\begin{tabular}{llll}
\hline Test & HQIC lags & Statistic & Result \\
\hline Kao (1999), Modified Dickey-Fuller t & 7 & $13.28^{* * *}$ & Cointegration \\
Westerlund (2005), Variance ratio & & $3.21^{* * *}$ & Cointegration \\
\hline
\end{tabular}

Note: H0: no cointegration vs. H1: all panels are cointegrated. $\mathrm{N}=106$ and $\mathrm{T}=18$

Table 6 Pesaran and Smith (1995) Mean Group (MG) estimation results

\begin{tabular}{lccc}
\hline Variable & Existence & Experience & Change \\
& & & \\
Control variables & & & \\
Price of wind turbines (first difference) & -0.00 & -0.00 & -0.00 \\
& $(0.00)$ & $(0.00)$ & $(0.00)$ \\
Coal price & 0.00 & 0.00 & 0.00 \\
& $(0.00)$ & $(0.00)$ & $(0.00)$ \\
GDP (first difference) & -0.00 & 0.00 & -0.00 \\
& $(0.00)$ & $(0.00)$ & $(0.00)$ \\
CO2 per GDP & $-3.88^{*}$ & $-3.98^{*}$ & $-4.10^{*}$ \\
& $(1.98)$ & $(2.30)$ & $(2.29)$
\end{tabular}

Strategic planning

\section{Policy variables}

Feed-in tariffs/premiums

$-0.09$

$(0.18)$

$-0.07$

$(0.08)$

Grants and subsidies

$-0.06$

$(0.05)$

Taxes

$0.03 * *$

$(0.01)$

$\mathrm{R} \& \mathrm{D}$

Codes and standards

Direct investment

Information and education

Voluntary approaches

Green certificates

Loans

Constant

Wald $\chi^{2}(15)$
$-0.01$

$(0.00)$

0.00

$(0.00)$

$-0.00$

$(0.01)$

0.01

$(0.01)$

$-0.01$

$(0.01)$

$-0.01$

$(0.01)$

0.13

(0.13)

$1.30 * * *$

$(0.50)$

40.71
0.06

$(0.04)$

0.02

$(0.01)$

0.05

(0.05)

$-0.07$

(0.07)

$-0.01$

(0.00)

0.01

(0.01)

0.01

(0.01)

$-0.00$

(0.01)

$-0.00$

(0.00)

$-0.00$

(0.00)

$-0.04$

(0.04)

$1.27 * *$

(0.61)

23.76
$0.09 *$

(0.05)

$-0.03$

(0.03)

$-0.12$

(0.08)

0.00

(0.02)

0.00

(0.02)

$-0.01$

(0.01)

$-0.15$

(0.18)

0.01

(0.01)

$-0.04$

(0.03)

$-0.00$

(0.00)

0.19

(0.19)

$1.35^{* * *}$

(0.57)

20.12 
Prob. $\chi^{2}$

0.00

0.07

0.17

Root mean squared error $(\sigma)$

0.36

0.39

0.34

Note: Dependent variable is wind energy (first difference). $N=106$ and $T=18$. Standard errors in parentheses. $* * * p<0.01, * * p<0.05, * p<0.1$ 